\title{
Belajar Sebagai Identitas Dan Tugas Gereja
}

\section{Learning as Church Identity and Duty}

\author{
Junihot M. Simanjuntak ${ }^{1)^{*}}$ \\ ${ }^{1)}$ Dosen Sekolah Tinggi Teologi Kharisma Bandung \\ *)Penulis korespondensi: junihots@gmail.com
}

Received: 15 January 2018/Revised: 12 February 2018 /Accepted: 16 March 2018

\begin{abstract}
Abstrak
Tulisan ini bertujuan untuk memaparkan pentingnya belajar dalam kaitannya dengan tugas pembinaan jemaat dan memaknainya sebagai tugas yang mendesak. Memakai metode deskriptif-analitis, penulis memaparkan konsep belajar dalam melalui pendekatan studi Alkitab dengan ilmu-ilmu psikologi sebagai pendukung. Hasil studi ini di dapatkan informasi bahwa l) Pendidikan Kristen Berbeda dengan pendidikan sekuler yang bercorak humanistik dan naturalistic. 2) Pendidikan Kristen berkonsentrasi pada tugas memahami dan menghayati serta mengkomunikasikan penyataan Allah (God's revelation) di dalam Alkitab dan di dalam Yesus Kristus. 3) dari studi Alkitab dikemukakan bahwa belajar adalah bagian dari hakikat manusia dan tuntutan dasariah dari Allah untuk mengenal Dia sebagai Tuhan Pencipta dan Penebus umat manusia. 4) Guna membimbing gereja berkembang dalam kehidupan yang dinamis secara spritual, kehadiran gereja yang bersedia belajar sangat diperlukan. Warga jemaat perlu disadarkan bahwa untuk memelihara kadar spiritualitas yang tetap segar, orang percaya senantiasa memerlukan pembelajaran yang jujur, sehat dan benar.
\end{abstract}

Kata-kata kunci: konsep, desain, kurikulum, tugas, pembinaan, gereja, warga jemaat.

This paper aims to describe the importance of learning in relation to the discipling duties of the church and interpret it as an urgent task. Using a descriptive-analytic method, the author explains concepts learned through a Bible study approach and includes discussion on psychology as a supplement. The results of this study in gathering information are that l) Christian Education is unlike secular education that is inclined toward humanistic and naturalistic thinking. 2) Christian Education is concentrated on the task of understanding and appreciating along with communicating the revelation of God (God's revelation) in the Bible and in Jesus Christ. 3) From studying the Bible it can be argued that learning is part of human nature and the basic demands of God to know Him as God the Creator and Redeemer of mankind. 4) In order to guide the church in developing spiritually dynamic lives, the presence of churches who are willing to learn is very much needed. The congregation needs to be made aware that to maintain levels of spirituality that will remain fresh and new, believers will continuously need learning that is honest, wholesome and true. 
Keywords: concepts, designs, curriculum, task, discipling, churches, church congregation

\section{Pendahuluan}

Gereja sedang dituntut oleh Tuhan Yesus untuk belajar dan berbuat untuk dirinya sendiri dan untuk orang lain juga bagi kemuliaan Allah. Hal inilah yang menjelaskan hakikat dan arti gereja yang melebihi dari tugas persekolahan sebagai lembaga pendidikan formal. Meskipun gereja adalah tubuh Kristus, umat Allah, dan pesekutuan orang percaya, namun ia juga merupakan institusi (lembaga) yang membawa umat untuk bertumbuh dalam iman kepada Allah melalui Yesus Kristus, oleh firman-Nya. Gereja terpanggil untuk melaksanakan tugas pendidikan atau pembinaan warga jemaat. Colson dan Rigdon ${ }^{1}$ mengemukakan empat alasan mengapa gereja harus memerlukan tugas ini, yaitu:

1. Karena diamanatkan oleh Tuhan Yesus Kristus, yakni memperlengkapi mereka yang percaya menjadi murid Tuhan (Mat. 28:19-20).

2. Injil menghendaki adanya pembelajaran, supaya mereka yang telah mendengar dan percaya Yesus Kristus, bertumbuh dalam iman, juga semakin memahami Injil itu sendiri.

3. Sejarah gereja menunjukkan bahwa dengan adanya pendidikan bagi warga, jemaat betumbuh dan berkembang. Kisah Rasul saja menunjukkan bahwa jemaat mula-mula aktif dalam kegiatan belajar (Kis. 2:24). Rasul Paulus sendiri aktif mendidik dan mengajari jemaat supaya bertumbuh dalam relasi yang dinamis bersama Yesus Kristus. Mereka juga dimampukan untuk memaknai kehidupan dengan berbagai pergumulannya.

4. Situasi zaman di mana gereja hidup menuntut pembinaan dan pendidikan. Nilai zaman yang berubah mengharuskan gereja melakukan tugas pendidikan dan pengajaran supaya mereka mampu membaca tandatanda zaman itu sendiri.

Kalau Amanat Agung Yesus hendak diwujudkan gereja, maka ia harus berpikir dan bertindak secara strategis. Dalam rangka menjadikan semua orang menjadi murid Yesus, pemberita Injil, pembaptisan dalam nama Allah Bapa, Anak dan Roh Kudus, serta pengajaran supaya orang percaya menjadi pelaku ajaran Kristus, maka kurikulum dibutuhkan. Caranya, melalui perencanaan dan pengembangan tugas dan panggilannya sebagai ciptaan Allah sebagai makhluk pembelajar.

Salah satu dari sekian banyak pergumulan yang sering dihadapi oleh para pendidik Kristen di gereja dalam beberapa dekade ini adalah kecilnya peran aktif dari warga jemaat untuk ikut terlibat dalam program

\footnotetext{
${ }^{1}$ Howard P. Colson, Raymon M. Rigdon, Understanding Your Church's Curriculum
} (Broadman Press, 1981), 18-19. 
pembinaan (terlebih dalam mengikuti pembelajaran pemahaman Alkitab). Berdasarkan hasil penelitian Michael Harton, hal itu terjadi karena warga jemaat itu sendiri merasa tidak menemukan kebutuhan mereka dalam pembinaan tersebut. Kurikulum yang diajarkan dalam pembinaan orang dewasa dianggap tidak lebih dari sebuah hasil dugaan atau orientasi dari kebutuhan para pendidik semata. ${ }^{2}$ McKenzie menyebut hal ini dengan istilah "penyimpangan"3 karena dianggap bahwa kebutuhan dari pendidik itu sendiri telah merenggut kebutuhan siswanya sendiri.

Bahkan menurut Robert Browning sebagaimana dikutip Ferris Jordan dalam artikelnya yang berjudul "Adult Life Structure", kebanyakan orang memberi tendensi kepada orang muda sebagai hidup yang penuh kegembiraan dan dinamis, dan menganggap orang dewasa sebagai orang yang bodoh, hidupnya statis dan tidak memiliki banyak hal yang menyenangkan. Banyaknya observasi yang dicurahkan kepada usia prasekolah, anak-anak, dan orang muda, semakin memperlemah perhatian yang diberikan kepada orang dewasa itu sendiri. Dilandasi oleh berbagai asumsi yang salah dan pemikiran palsu tentang orang dewasa pada akhirnya memberi label bahwa "orang dewasa" tidak pantas menerima pembinaan khusus. ${ }^{4}$

Allah juga menciptakan alam semesta untuk kemuliaan-Nya dan menempatkan manusia dalam dunia ini sebagai bendahara-Nya. Kepada manusia yang diciptakan menurut rupa dan gambar-Nya itu Allah memberikan mandat kultural (bdg. Kej 1:28-29). Dengan demikian manusia terpanggil untuk mengelola alam semesta bagi kemuliaan Sang Khalik dan bagi kepentingan manusia itu sendiri. Ini menjadi landasan dalam menanamkan tanggungjawab hidup seutuhnya. Pemahaman ini harus dimengerti oleh peserta didik, agar terus mendorongnya berkarya bagi kemuliaan Allah.

Alkitab mengajarkan manusia berdosa, akibat pembrontakan manusia pertama, dalam ruang dan waktu tertentu di masa lalu (bdg. Kej. 3:1-25). Akibatnya manusia yang membawa gambar dan rupa Allah itu, mengalami dan menghadapi berbagai masalah dalam dirinya, termasuk rasa malu, rasa bersalah, tertolak, tak berdaya dan jauh dari hadirat Sang Pencipta. Dosa membuat manusia tidak mengalami keutuhan dalam dirinya, ia juga melakukan berbagai pelanggaran moral dan spiritual serta pelanggaran sosial terhadap sesamanya. Dosa dan akibatnya sangat

${ }^{2}$ R. Michael Harton, "Program Planning Models for Adult Christian Education," dalam A Church Ministering to Adults (Nasville, Tennessee: Broadman Press, 1986), 144.

${ }^{3}$ Leon McKenzie, The Religion Education of Adults (Birmingham, Ala: Religious Education Press, 1982), 139.

${ }^{4}$ C. Ferris Jordan, "Adult Life Structure" dalam A Church Ministering to Adults (Nasville, Tennessee: Broadman Press, 1986), 33. 
merusak (destruktif), mendatangkan maut. Secanggih apapun, pendidikan dan pembelajaran secara humanistik dan naturalistik upaya itu tidak akan mampu melenyapkan realitas dosa dalam kehidupan manusia. Dosa membuat manusia senantiasa menghindarkan diri dari kebenaran sejati, menggap dirinya pintar dan menggantikan kemuliaan atau kebenaran Allah (bdg. Rom 1:18-32).

Oleh sebab itulah manusia membutuhkan pemulihan, pendamaian dengan Allah, agar gambar dan rupa Allah itu dipulihkan kembali. Allah sudah melakukan itu di dalam dan melalui Yesus Kristus lewat karya-Nya di salib serta lewat kebangkitan-Nya. Panggilan Allah bagi manusia adalah berpaling kepada-Nya di dalam dan melalui Yesus Kristus. Inilah tindakan iman yang nyata dalam pertobatan. Dengan pemahaman ini, pendidikan Kristen tidak berhenti sebatas mengajarkan berbagai pengetahuan dan keterampilan hidup, tetapi juga menjadi agen pemberita Injil, kasih dan anugerah Allah di dalam Tuhan Yesus Kristus. Pendidikan yang namanya Kristen karena kasih Allah yang dimengerti dan dialaminya haruslah setia terhadap pemberitaan Injil ini sebab hal itulah kuasa yang mengubah kehidupan (bdg. Mat. 28:19-20; Rm. 1:16-17).

Roh Kudus juga hadir di dunia dan dalam kehidupan orang Kristen (orang percaya) untuk memampukan mereka mengemban tugasnya sebagai bendahara Allah di dunia. Roh itu memberikan hikmat, kebijakan, menuntun orang ke dalam kebenaran sebagaimana dijelaskan Alkitab dan dalam kebenaran yang berada dalam Yesus Kristus (bdg. Yoh. 16:6-13). Tanpa pemulihan oleh pekerjaan Roh Kudus, murid yang walaupun terpelajar, pintar dalam berbagai bidang pengetahuan, tetap tidak berdaya melawan kuasa dosa yang destruktif dalam dirinya. Kemerdekaan batin terjadi dalam kehidupan karena pekerjaan Roh Allah yang menyatakan kuasa Yesus Kristus (bdg. 2 Kor. 3:7-18; Rm. 8:5-11). Filsuf Kristen Francis A. Schaeffer pernah berkata bahwa manusia tanpa Allah melalui Yesus Kristus hidup dalam keputusasaan, tidak mempunyai dasar dan tujuan hidup yang jelas. ${ }^{5}$

Untuk mencapai tujuan itu tentunya, diperlukan pendidik atauguru Kristen yang sungguh-sungguh mengenal Allah di dalam Yesus Kristus, mengalami pembaruan spiritual; memiliki konsep epistemologi bahwa semua kebenaran bersumber dari Allah di manapun kita memperolehnya dan ukurannya ialah firman Allah sendiri; memiliki panggilan keguruan yang dipandangnya sebagai karunia Allah bukan karena mempertahankan hidup; mengasihi dan mendoakan muridnya dengan kasih Allah dan rindu membawa mereka berjumpa dengan Allah

${ }^{5}$ Francis A. Schaeffer, dalam The God Who Is There (InterVarsity Press, 1998), IV; dan Karya Scaeffer yang lain dalam He Is There He Is Not Silent (Wheaton, Ill., Tyndale House Publishers, 1972), 148; dan selanjutnya dalam karya klasiknya yang berjudul Escape from Reason (InterVarsity, 1968), 87. 
sang sumber kebenaran; mempunyai etos kerja yang senantiasa diperbarui oleh Roh Kudus, sehingga mengijinkan dirinya digunakan Allah sebagai saluran kuasa dan hikmat serta kasih; mampu membedakan kebenaran dengan kepalsuan (discerning spirit)serta memahami dirinya bagian dari umat beriman atau tubuh Kristus (komuntitas beriman) di dunia ini, sehingga dia rela belajar dari orang lain dan juga bekerjasama dengan mereka.

Guru (pendidik) Kristen harus mempunyai kesadaran teologis tentang pentingnya masalah integrasi iman dengan pengetahuan dan dengan proses pendidikan. Ia tidak saja melihat hubungan atau korelasi antara iman dengan pengetahuan yang diajarkan, tetapi berusaha mengembangkan dua atau beberapa konsep menjadi satu dengan warna khas untuk seterusnya dikembangkan. Warna khas yang dimaksud di sini ialah prinsip-prinsip iman Kristen mengenai kebenaran dan pengetahuan. Tugas pengintegrasian ini memang tidak mudah, diperlukan wawasan dan keterampilan yang bertumbuh dari latihan-latihan. Untuk memahami apa itu pengintegrasian, saya mengemukakan gagasan Ronald Chadwick berikut:

Integration is the bringing together of parts into a whole, and so integration in Christian education is the living union of not only concepts with concepts, of truth with truths, but the living union of the subject matter with life - the eternal, infinite patterns of God's written Truth woven together with all truth and all of life. ${ }^{6}$

Untuk membawa murid mengenal Allah metode pembelajaran tidak hanya padainformingtetapi juga conformingdantransforming. Peran guru tidak hanya memberikan ceramah, cerita dan kuliah (to inform). Pemberian informasi merupakan upaya mengupayakan perubahan hidup dengan pendekatan outside-indari luar ke dalam diri peserta didik. Guru harus membimbing muridnya hidup bersesuaian dengan apa yang dipelajari (to conform). Lebih jauh dari upaya ini, guru dengan pertolongan hikmat atau kreatifitas Roh Tuhan, sedemikian rupa melalui relasi dialogisnya, melalui keteladannya, membawa murid mengalami pembaruan dalam dirinya karena berjumpa dengan kebenaran yang memerdekakan di dalam Yesus Kristus (to transform). Perubahan dialami peserta didik dengan arah inside-

\footnotetext{
${ }^{6}$ Company (1982), 54-55. Ide Chadwick ini sebenarnya dikembangkan dari pemikiran Frank E. Gaebelein dalam The Patterns of God's Truth: The Integration of Faith and Learning (Moody Press, 1968), 11. Menurut Gaebelein, integrasi sesuai dengan prinsip kebenaran yang dikemukakan Alkitab, juga sesuai dengan cita-cita pendidikan itu sendiri. Integrasi dalam pendidikan bukan saja terjadi hanya di antara bahan pengajaran dengan kebenaran tetapi juga di antara guru itu sendiri dengan kebenaran dan pengetahuan yang disampaikannya kepada para murid.
} 
out atau dari dalam diri keluar melalui ekpresi diri. Prinsip kerjanya adalah bahwa di samping membimbing murid belajar tentang disiplin ilmu, guru juga berperan sebagai pemberita Injil dan pembuat murid Tuhan. Dengan demikian, diharapkan murid mengenal siapa penciptanya, asal dan tujuan hidupnya dan makna dari dirinya dalam dunia, sebagai rekan sekerja Allah melalui tugas yang diberikan kepadanya. Keseimbangan antara pengajaran disiplin pengetahuan dengan pembinaan spiritualitas harus berlangsung atau terpelihara dengan baik.

Sekolah dan perguruan tinggi Kristen sebagai lembaga (institusi) harus menunjukkan peran sosial dan kulturalnya. Ada fungsi sosialisasi dari pendidikan Kristen, sesuai dengan ajaran Alkitab bahwa manusia adalah makhluk sosial ciptaan Allah. Sekolah harus menjadi wakil gereja (loco ecclesia) dan wakil keluarga (loco parentis) dalam membawa peserta didik berintraksi secara sehat dengan sesamanya. Untuk tujuan ini maka sekolah harus memfasilitasi aktifitas di mana peserta didik menerima dirinya sebagai makhluk sosial dan mengembangkan berbagai keterampilan sosialnya termasuk berelasi dengan sesama, berkomunikasi dengan orang lain secara efektif. Hidup bersama dengan orang lain dengan semua keunikannya, harus dipelajari oleh peserta didik di sekolahnya. Bagaimana murid memperlakukan rekannya yang berbeda dengan dirinya? Bagaimana pula guru memberi teladan dalam memperlakukan murid yang berbeda keyakinannya atau yang berbeda sikap dan pandangan dengan dirinya? Terpojokkah murid demikian? Merasa nyamankah? Program-program peningkatan keterampilan sosial dan pembinaan karakter peserta didik harus menjadi salah satu ciri khas pendidikan Kristen. ${ }^{7}$ Pendidikan Kristen tidak boleh puas kalau proses belajar di kelas sudah tuntas.

Terkait dengan pemikiran sebagaimana telah dipaparkan di atas, tulisan ini dimaksudkan untuk mengulas lebih lanjut tentang belajar sebagai identitas dan tugas gereja, yang diawali dengan melihat landasan Alkitab, dan selanjutnya diteruskan dengan pembahasan dan diskusinya dalam perspektif para pemikir pendidikan Kristen.

\section{Kajian Pustaka}

Identitas Manusia Sebagai Pembelajar Menurut Alkitab dan Aspek Psikologis

Untuk memperjelas sudut pandang tentang manusia: identitas dan sekaligus tugasnya sebagai makhluk pembelajar (pendidik dan sekaligus

${ }^{7}$ Bukan hanya kita di sini yang bergumul tentang penanaman nilai hidup moral dan sosial ini. Pergumulan penanaman nilai dan moral dalam pendidikan Kristen melalui interasi di kelas dan di luar kelas dalam sejumlah lembaga pendidikan Kristen di Amerika dibahas dalam karya Ken Sidney, The Blackboard Fumbleed (Wheaton, IL: Victor Books, 1989), 95-97. 
sebagai peserta didik), maka dalam pembahasan ini akan dipaparkan tentang pemahaman tentang identitas manusia sebagai makhluk pembelajar. Hal ini dimaksudkan agar para pendidik Kristen dapat memahami dan mengembangkan prinsip-prinsip serta praktik pendidikan Kristen dalam konteks pendidikan formal maupun tidak formal dari persfektif psikologi dan Alkitab. Yang mana hal-hal yang tidak dapat dipahami oleh psikologi tentang manusia dapat dijelaskan oleh pemahaman Alkitab tentang manusia itu sendiri. Sehingga pedagogi pendidikan yang kita terapkan dapat lebih optimal dalam membelajarkan para peserta didik.

\section{Identitas Manusia Sebagai Pembelajar menurut Alkitab}

Banyak buku psikologi pendidikan dan psikologi belajar yang dapat menolong kita bagaimana memahami cara belajar manusia, serta aplikasinya bagi tugas pembelajaran. Akan tetapi pada umumnya teori itu muncul dari asumsi bahwa manusia pada dasarnya baik, juga merupakan buah evolusi. Dengan pendekatan behavioristik, teori belajar dirumuskan dari percobaan terhadap binatang (anjing, burung, dll). Dengan pendekatan kognitif, teori belajar dikembangkan dari pemahaman bahwa manusia memiliki pikiran (otak) yang memengaruhi sikap dan perilakunya.

Dengan pendekatan humanistik, teori belajar dikembangkan dari pengertian bahwa manusia mempunyai kebutuhan seperti fisiologis, rasa aman, dikasihi dan mengasihi, rasa memiliki dan aktualisasi diri yang merupakan pemikiran Maslow.

Sebagai orang Kristen yang percaya kepada Alkitab, sabda Allah, kita seharusnya mempertimbangkan penjelasannya mengenai manusia. Kalau menurut psikologi belajar pada umumnya manusia memiliki tubuh, pikiran, emosi dan jiwa (soul). Menurut Alkitab manusia juga memiliki hati, suara hati (hati nurani) dan roh (spirit). Jika demikian, maka ketika manusia belajar, semua aspek itu akan aktif dan saling terkait satu sama lainnya.

Untuk lebih jelasnya, marilah kita pertimbangkan sejumlah informasi Alkitab mengenai siapa dan apa manusia itu.

Pertama, dalam Kejadian 1:26, 27 menjelaskan bahwa manusia adalah ciptaan Allah yang membawa rupa dan gambar-Nya. Kalau Allah berpribadi, maka manusia juga berpribadi. Allah memberikan berbagai potensi dalam diri manusia, seperti kemampuan berkomunikasi, berpikir, merasakan, juga berbuat, agar mempermuliakan Dia.

Kedua, dalam Kejadian 2:7 mengemukakan bahwa manusia yang diciptakan Allah itu terbentuk dari debu tanah dan padanya dihembuskan nafas kehidupan (Ibr.nefeshayyah). Jika demikian, manusia sebagai individu (pribadi) memiliki dimensi fisik (jasmani) yang terikat kepada 
alam. Di samping itu, manusia memiliki aspek non-fisik atau rohani (spiritual). Adanya nefes hayyah itu membuat manusia membutuhkan Allah di dalam seluruh kehidupannya.

Ketiga, dalam Injil Markus 12:29 dan 30 menegaskan perkataan Yesus agar kita mengasihi Allah dengan segenap hati, jiwa, kekuatan dan akal budi. Itu berarti pada diri manusia terkandung aspek lahiriah dan non lahiriah; aspek material dan non-material dalam satu kesatuan. Hati biasanya dianggap sebagai pusat kehidupan dalam diri manusia, tempat pertimbangan, perasaan, dan sikap, juga kehendak. Jiwa, biasanya diartikan sebagai perasaan. Kekuatan terkait dengan fisik, jasmani, penginderaan, sistem syaraf dan endokrin. Akal budi merupakan komponen yang membuat manusia mengerti dan memahami.

Keempat, dalam Injil Lukas 2:40, 52 menjelaskan bahwa Tuhan Yesus bertumbuh dalam fisiknya, dalam hikmatnya, dalam spiritual dan dalam aspek sosialnya. Kalau mau bertumbuh dalam keutuhan, maka kita harus mengakifkan semua dimensi itu.

Kelima, dalam Kitab 1 Tesalonika 5:23 mengemukakan ucapan berkat rasul Paulus. Di dalamnya terkandung konsep manusia terdiri dari tubuh, jiwa dan roh. Tubuh berkaitan dengan panca indra. Jiwa sering diartikan terkait dengan pikiran (akal), emosi (perasaan), dan kehendak (will). Roh (pneuma - Yun) terkait dengan dimensi yang membuat kita mampu merespons komunikasi Allah yang adalah roh adanya (Yoh. 4:24).

Keenam, dalam Kitab Ibrani 4:12 mengindikasikan bahwa manusia memiliki roh dan jiwa; itu berarti aspek roh (pneuma) memiliki perbedaan dengan jiwa (psyche). Menurut pendapat saya, roh manusia berhubungan dengan Tuhan. Jiwa terkait dengan diri sendiri dan lingkungan sosial kita. Efek dari lingkungan kita respons melalui jiwa - akal, pikiran, kehendak.

Ketujuh, dalam Ibrani 9:14 menunjukkan bahwa manusia juga memiliki suara hati yang perlu disucikan oleh darah Kristus dari segala kejahatan supaya dapat beribadah kepada Dia dengan benar. Roma 2:14,15; 9:1 menegaskan bahwa suara hati (Yun. syneidesis) menjadi tanda bahwa manusia adalah ciptaan Tuhan. Ada banyak nas Alkitab yang juga berbicara tentang suara hati ini seperti dalam Roma 13:5; 1 Kor. 8:7, 10, 12; 10:28, 29; 2 Kor. 4:2; 1 Ptr. 2:19; Kis. 23:1; 24:16; 1 Tim. 1:5, 19; 3:9; 4:2; 2 Tim. 1:3; Tit. 1:15; Ibr. 10:22; 13:18; 1 Ptr. 3:16, 21. Kalau demikian apa artinya hal ini bagi aktivitas belajar? Ruth Beechick dalam tulisannya A Biblical Psychology of Learning ${ }^{8}$ mengemukakan bahwa dalam Alkitab terdapat 800 lebih istilah hati, sedangkan pikiran hanya sekitar 80 kali. Itu berarti, menurut Beechick, hati sangat sentral dalam kegiatan belajar. Hati anak didik atau pelajar harus dipersiapkan dimotivasi, supaya memiliki

\footnotetext{
${ }^{8}$ Ruth Beechick, Biblical Psychology of Learning (Acćent Books, 1982), 37-40.
} 
ketetapan (heart set), komitmen untuk belajar dan berdisiplin, sehingga hatinya sangat mengasihi Tuhan. Pikiran diaktifkan melalui informasi. Dalam pemahaman Beechick, kasih dan penerimaan orangtua atau guru amat sentral dalam menyiapkan hati anak untuk giat mencari dan mempertimbangkan informasi yang didengar dan dibacanya.

\section{Identitas Manusia Sebagai Pembelajar Menurut Aspek Psikologis}

Manusia merupakan subjek dalam kehidupan, sebab sebagai makhluk ciptaan Tuhan, dialah yang selalu melihat, bertanya, berpikir dan mempelajari segala sesuatu yang ada dalam kehidupannya. Manusia bukan hanya tertarik mempelajari apa yang ada pada lingkungannya atau sesuatu di luar dirinya, tetapi juga tentang hal-hal dirinya. Dengan kata lain, manusia ingin mengetahui keadaan manusia sendiri, manusia menjadi objek studi dari manusia. Dasar-dasar pemahaman dan pengkajian tersebut diambil dari suatu cabang ilmu yang disebut psikologi. ${ }^{9}$

Bukankah ada ilmu-ilmu lain, selain ilmu psikologi yang menjadikan manusia sebagai objek studinya? Jawabnya Ya! Contohnya seperti:

a. Ilmu Fisiologi, yang mempelajari aspek fisik atau jasmani manusia, seperti struktur tubuh, bagian-bagian tubuh serta fungsi dan cara kerja tubuh.

b. Sosiologi, yang mempelajari manusia dalam berbagai satuan kelompok kecil seperti dalam satuan keluarga, unit-unit pekerjaan, organisasi, kelompok profesi, kelompok-kelompok masyarakat, dan lain-lain.

c. Antropologi, yang mempelajari manusia dalam kelompok-kelompok manusia yang lebih besar dan terikat dalam sebuah ikatan yang lebih permanen, turun-temurun, seperti kelompok ras, bangsa, suku bangsa, kebudayaan, dan lain-lain.

d. Sejarah, yang mempelajari kehidupan manusia dalam urutan waktu dan peristiwa yang dialaminya.

Lalu, apa yang membedakan ilmu psikologi dan ilmu-ilmu lainnya yang sama-sama menjadikan manusia sebagai objek studinya? Jawabnya, psikologi selain mempelajari manusia dari aspek fisik, juga ia mempelajari manusia dari perilaku atau kegiatannya secara individu (Yun: in dividuum; Ingg: undivided) = tidak dapat dipisahkan (jasmani dan rohani, atau fisik dan psikis).

Psikologi memandang manusia dari sisi individu. Individu memiliki ciri yang esensial, yaitu bahwa dia selalu berperilaku atau melakukan kegiatan. Individu diakui sebagai individu selama ia masih melakukan kegiatan atau berperilaku, apabila tidak ia bukan individu lagi.

\footnotetext{
${ }^{9}$ Nana Syaodih Sukmadinata, Landasan Psikologi Proses Pendidikan (Bandung: Rosadakarya, 2007), 15.
} 
Perilaku (behavior) atau kegiatan (activity) adalah segala manifestasi hayati atau manifestasi hidup individu, yaitu semua ciri-ciri yang menyatakan bahwa individu manusia itu hidup. Perilaku ini tidak hanya mencakup hal-hal yang dapat diamati (overt) tetapi juga hal-hal yang tersembunyi (covert). Dapatkan Anda menyebutkan contoh perilaku yang dapat diamati, dan contoh perilaku yang tersembunyi?

Individu selalu berada dalam lingkungan tertentu oleh sebab itu harus dipahami juga bahwa individu juga selalu berlangsung dalam interaksi dengan lingkungannya.

Dalam literatur psikologi pada umumnya para ahli ilmu ini berpendapat bahwa penentu perilaku utama manusia dan corak kepribadian adalah keadaan jasmani, kualitas kejiwaan, dan situasi lingkungan. Determinan tri dimensional ini (organo biologi, psikoedukasi, dan sosiokultural) merupakan determinan yang banyak dianut oleh ahli psikologi dan psikiatri. Dalam hal ini unsur rohani sama sekali tidak masuk hitungan karena dianggap termasuk penghayatan subjektif semata-mata.

Dari keterangan di atas dapat saya kemukakan beberapa prinsip mengeai identitas manusia sebagai makhluk pembelajar bertolak dari konsep manusia menurut ajaran Akitab dan aspek psikologi. Pertama, manusia makhluk berdimensi fisik (jasmani), yang menurut sains memiliki syaraf, kelenjar, kerangka, sistem pencernaan, sistem pernafasan, sistem sirkulasi, sistem pembuangan. Kesehatan fisik memmemengaruhii aktivitas belajar. Pengindraan penting dalam kegiatan belajar; informasi diperoleh lewat penginderaan dan kita membentuk persepsi, bahkan mengingat apa yang kita anggap berkesan dan bermakna.

Kedua, manusia makhluk sosial. Ia membutuhkan sesamanya, baik sejenis maupun lawan jenisnya (Kej. 2:18, 24-25). Orang tua dan anak saling melengkapi dalam kegiatan belajar di dalam perjalanan hidup mereka. Manusia saling mengasah, demikian tegas Amsal 27:17; juga ada efek pergaulan terhadap kepribadian dan watak orang. Keluarga merupakan komunitas primer dalam pembelajaran manusia. Anak diajar oleh orangtuanya sebelum memasuki tetangga, sekolah dan gereja. Berbagai keterampilan dasar dipelajari anak dalam keluarga - pola-pola komunikasi dan disiplin serta nilai hidup. Bahasa juga dipelajari dalam konteks ini. Dalam Perjanjian Baru, komunitas orang percaya (gereja) sangat ditekankan dalam rangka pembelajaran (Kis. 2:42-47; Kol. 3:15-16; Ibr. 10:24, 25). Iman bertumbuh dalam interaksi komunitas, yang beribadah kepada Tuhan, juga aktif berdoa dan saling melayani. Yesus mengatakan bahwa perkumpulan orang percaya wadah kehadiran-Nya (Mat. 18:19-20). Dia datang untuk membangun jemaat-Nya di bumi (Mat. 
16:18). Aneh bila ada tendensi orang percaya ingin belajar tetapi memisahkan diri dari komunitas.

Ketiga, manusia makhluk alam. Itu berarti alam juga memengaruhi manusia dalam kegiatan belajar. Kitab Amsal menegaskan agar manusia belajar kepada alam, tumbuhan dan binatang - semut, cicak, pelanduk, belalang, dll. Yesus juga memakai cerita alam untuk mengajarkan Kerajaan Allah - penabur benih; biji sesawi; nelayan dan pukat; pembuat adonan; juga tindakan mengubah air menjadi anggur atau memberi makan 5000 orang dengan lima roti dan dua ikan. Yesus mengajar murid-murid di berbagai lokasi, di perahu, di tepi danau, di atas bukit, di rumah, di sinagog, dll. Di malam hari, Yesus beristirahat, karena begitulah hukum alam yang harus ditaati di mana kita beristirahat.

Keempat, manusia makhluk rasional. Pikiran atau akal budi harus digunakan bagi kemuliaan-Nya. Belajar merupakan aktivitas nalar. Pola nalar harus dikembangkan supaya memahami dengan baik dan benar. Pikiran harus mendapat pembaruan (Rm. 12:2). Pikiran harus dilatih untuk hal positif (Flp. 4:4).

Kelima, manusia makhluk spiritual. Roh manusia aktif dalam belajar untuk pertumbuhan imannya. Ketika roh manusia didiami oleh Roh Allah, dipenuhi, dipimpin-Nya, maka ia semakin memahami kebenaran dan hidup sesuai kebenaran Tuhan. Roh itu memampukan roh manusia mengerti perkara-perkara iman. Roh itu menumbuhkan akhlak moral (Gal. 5:22-23).

Keenam, manusia makhluk bersuara hati. Jika demikian maka pembentukan suara hati sangat perlu kita perhatikan dalam belajar. Kalau suara hati orang lemah maka semangat dan keputusannya juga lemah. Suara hati harus disucikan oleh darah Kritus. Suara hati harus tunduk pada otoritas Yesus. Suara hati harus diperkaya oleh firman Tuhan.

Belajar menurut konsep Alkitab sangat kompleks, dan berlangsung dalam setiap detik kehidupan kita. Satu hal penting lagi, bahwa tujuan belajar manusia ialah mengenal Allah Tritunggal yang kudus, hingga mengasihi Dia dengan segenap hati, jiwa, kekuatan dan akal budi, juga dengan suara hati yang bersih. Seperti Allah berbicara dengan berbagai cara kepada manusia (Ibr. 1:1-3), manusia juga belajar mengenal Dia, mengenal dirinya, serta mengenal sesama dan lingkungannya dengan berbagai pendekatan. Peniruan, pembiasaan, aktivitas mendengar, melihat, mencecap, mencium, menyentuh, melakukan, juga merasakan, semua penting dalam kegiatan belajar. Kreativitas menjadi sangat penting dalam kehidupan ini.

\section{Tugas Gereja dalam Pembelajaran}

Melihat pentingnya landasan teologi dalam tugas pembelajaran (belajar dan mengajar) yang dilakukan oleh gereja, maka berdasarkan 
hasil studi pustaka, saya menemukan tiga hal yang dapat dijadikan sebagai landasan teologi yang kuat bagi alasan untuk pelaksanaan tugas gereja dalam mengajar warga jemaat memahami identitas dan tugasnya dalam belajar. Pertama, berdasarkan perintah langsung dari Tuhan Yesus dalam Keempat Injil..$^{10}$ Di dalam keempat Injil terdapat sebanyak delapan puluh sembilan kali mengacu pada Yesus sebagai seorang guru; sementara mengacu pada Dia sebagai seorang pengkhotbah hanya dua belas kali. Pengajaran selalu menjadi bagian yang sentral di dalam segala hal yang Yesus lakukan. Yesus sendiri mengharapkan bahwa gereja-Nya harus menjadi gereja pengajaran sebagaimana yang terdapat dalam Amanat Agung dalam Matius 28:18-20: “... dan ajarlah mereka melakukan segala sesuatu seperti yang telah Kuperintahkan kepadamu...” Setiap bagian dari panggilan itu orientasinya adalah program pengajaran dan pelatihan. Oleh sebab itu, setiap kali gereja mengkhotbahkan pesan Allah yang bersifat menebus, juga di waktu yang sama gereja harus mengajarkannya. Wahyu dan pendidikan tidak dapat dipisahkan. Mengajar Injil adalah satu cara penting untuk penyebarannya. Hal ini yang memaksa alasan mengapa gereja-gereja harus mengajar tiap-tiap anggota jemaatnya.

Kedua, teladan jemaat yang mula-mula dalam Kisah Para Rasul 2:4247. Sejak mulai berdirinya gereja pada hari pentakosta, jemaat Kristen menjunjung sekali pengajaran. Mereka segera mengembangkan perkumpulannya dengan mengisinya dengan doa, bertekun dalam pengajaran rasul-rasul dan perbuatan-perbuatan kasih seperti yang dikehendaki Tuhan Yesus Kristus, mereka makan sehidangan dan merayakan perjamuan suci (ayat 42). Mereka mulai berkhotbah supaya banyak orang lain percaya pada Yesus Kristus sebagai Penebus dan Tuhan. Dan mereka yang bertobat dan mau bergabung dengan jemaat Kristen itu, didik dengan saksama. Mereka belajar tentang Diri dan pekerjaan Juruselamat, dan juga tentang panggilan dan tugas seorang Kristen di dunia ini. ${ }^{11}$

Ketiga, mengacu pada tugas gereja. Robert W. Pazmino mengemukakan ada lima tugas gereja berdasarkan 1 Korintus 12:4-7, yaitu: pemberitaan Injil (kerygma), persekutuan (koinonia), pelayanan sosial (diakonia), pembelaan (propheteia) dan ibadah (litourgeia). Namun aspek pengajaran (didache) tidak dimasukkan di dalamnya karena pengajaran (didache) dianggap sebagai penghubung bagi kelima tugas gereja

${ }^{10}$ Howard P. Colson dan Raymond M. Rigdon, Understanding Your Church's Curriculum (Nashville, Tennessee: Broadman Press, 1981), 15-16.

${ }^{11}$ Homringhausen dan Enklaar, Pendidikan Agama Kristen, 8. 
tersebut. ${ }^{12}$ Intinya, pengajaran Kristen berfungsi untuk mempertemukan Allah dengan manusia, dan Alkitab adalah sumber utamanya. ${ }^{13}$

Tetapi menurut $\mathrm{H}$. Hadiwijono tugas gereja hanya dua, yaitu pertumbuhan ke dalam dan pertumbuhan ke luar. Pertumbuhan ke dalam adalah tugas gereja mendidik umatnya agar mencapai kesatuan dan kedewasaan iman serta pengetahuan yang benar tentang Kristus (Ef. 4:13, 14). Pertumbuhan keluar diartikan sebagai pemberitaan Injil ke seluruh dunia. ${ }^{14}$

Terkait dengan tugas gereja ke dalam tersebut, pendidikan Kristen adalah merupakan suatu fungsi gereja yang amat penting, suatu pemberian dan amanat Tuhan sendiri kepada jemaat-Nya yang seharusnya ditanggung dan dilaksanakan oleh gereja sendiri. Untuk itu Tuhan sendiri telah memanggil dan mengangkat dari anggota-anggota gereja "rasul-rasul, nabi-nabi, pemberita-pemberita Injil, gembalagembala dan pengajar-pengajar" (Ef. 4:11). ${ }^{15}$

\section{Metodologi}

Dalam penelitian ini, metode yang digunakan adalah metode deskriptif dengan pendekatan kualitatif. Penggunaan metode dan pendekatan tersebut mengingat bahwa tujuan dari penelitian ini adalah untuk mendiskripsikan tentang belajar sebagai identitas dan tugas gereja, dengan melakukan pendekatan studi pustaka sebagai sumber informasi sebagai kegiatan pengumpulan data.

Deskripsi tersebut sesuai dengan pernyataan Sukardi ${ }^{16}$ bahwa "Metode penelitian deskriptif merupakan metode penelitian yang berusaha menggambarkan obyek atau subyek yang diteliti sesuai dengan apa adanya dengan tujuan menggambarkan secara sistematis fakta dan karakteristik subyek yang diteliti secara cepat." Dari deskripsi tersebut dapatlah dipahami bahwa pendekatan kualitatif adalah suatu pertanyaan mengenai hakikat gejala atau pertanyaan mengenai apa itu atau mendeskripsikan tentang apa itu, sehingga diperoleh informasi keadaan gejala yang sedang berlangsung sebagai pemecahan masalah yang ada, masalah yang hangat dan aktual, dalam bentuk kata atau kalimat sehingga memberikan makna.

\footnotetext{
${ }^{12}$ Robert W. Pazmino, God Our Teacher (Grand Rapids, Michigan: Baker Academic, 2001), 114.

${ }^{13}$ Pazmino, 118. Pazmino mengutip pendapat Millard Ericson.

${ }^{14}$ H. Hadiwijono, Iman Kristen (Jakarta: BPK Gunung Mulia, 1979), 384-388.

${ }^{15}$ Homringhausen dan Enklaar, Pendidikan Agama Kristen, 20-21.

${ }^{16}$ Sukardi, Metodologi Penelitian Pendidikan: Kompetensi dan Praktiknya (Jakarta: Bumi Aksara, 2005), 157.
} 
Subjek dalam penelitian ini adalah gereja dan seluruh warga gereja itu sendiri. Moleong mengemukakan bahwa subjek penelitian pada penelitian kualitatif adalah sampel bertujuan artinya menjaring informasi dari berbagai macam sumber dan bentuknya sehingga dapat dirinci kekhususannya yang ada dalam konteks yang unik. ${ }^{17}$

Dalam menemukan data yang benar tentang belajar sebagai identitas dan tugas gereja, peneliti mengunakan teknik pengumpulan data melalui observasi, wawancara dan studi dokumentasi. Selanjutnya untuk menganilisis data yang telah dikumpulkan sejak awal penelitian sampai akhir penelitian dengan teknik reduksi data, penyajian data dan kesimpulan.

\section{Pembahasan dan Diskusi}

Maria Harris menjelaskan lima tugas gereja dan panggilan gereja, ${ }^{18}$ yaitu: (l) Koinonia (persekutuan) pembentukan dan pemerkayaan komunitas; agar gereja merasakan diri sebagai keluarga yang hidup dalam kasih, saling membantu, saling menopang, dll; (2) Liturgi (ibadah) - doa, pujian, penyembahan, pemberitaan firman. Dengan cara apa dan atau bagaimana supaya gereja beribadah dengan baik dan benar sesuai dengan ajaran Alkitab, berjumpa dengan Tuhan melalui firman-Nya? Apa yang harus dilakukan supaya gereja memahami tujuan, fungsi ibadah? Bagaimana kurikulum khotbah? Bahan atau temanya? Lagu-lagu yang tepat? Musik yang mengiringinya? Doanya pribadi atau doa kelompok?; (3) Pengajaran (didache) - apa yang mesti dipelajari, dipahami oleh warga jemaat? Bagaimana kegiatan belajar harus dikelola supaya warga jemaat terlibat di dalam tugas gereja untuk mengajar? Siapa yang harus mengajar siapa? Apakah hanya orang-orang tertentu? Di mana kegiatan belajar warga jemaat dapat berlangsung? Berapa lama? Untuk apa?; (4) Kerygma atau pemberitaan Injil. Dengan cara bagaimana jemaat memahami dan bahkan terlibat aktif di dalam pemberitaan Injil? Dengan pengajaran Alkitabkah? Dengan perumusan konsep teologis? Cukupkah melalui khotbah kita mendorong agar warga jemaat aktif dalam tugas ini? Aktivitas apa yang dapat kita upayakan supaya jemaat mengemban tugas ini?; (5)Diakonia - bagaimana ajaran Alkitab mengenai pelayanan ini? Bagaimana bentuknya dalam jemaat masa kini? Bagaimana menyadarkan, memobilisasi potensi jemaat untuk aktif dalam tugas ini? Kurikulumnya apa? Strategi pembelajarannya bagaimana?

\footnotetext{
${ }^{17}$ Lexy J. Moleong, Metodologi Penelitian Kualitatif (Bandung: Remaja Rosdakarya, 2006), 65.

${ }^{18}$ Maria Harris, Fashion Me a People:Curriculum in the Church (Louisville, KY Westminster John Knox Press, 1989), 12.
} 
Menurut Sidjabat, jika kita meninjau ajaran Alkitab, berikut ini adalah sejumlah tugas gereja yang tidak boleh diabaikan, di antaranya: a) Untuk beribadah dan memuliakan Allah (1 Ptr. 2:9, 10b) Untuk mendidik warganya melaksanakan berbagai panggilan gereja (Kis. 2:42-47); c) Melaksanakan Amanat Agung Kristus (Mat. 28:19-20). Termasuk di dalamnya tugas mengajar warga supaya mampu melakukan apa yang diajarkan Yesus Tuhan; e) Gereja harus mengajar (Kol. 3:15-16); f) Agar bertumbuh menjadi dewasa dan melayani ke dalam dan ke luar (Ef. 4:1116); g) Agar gereja mampu menghadapi berbagai ajaran yang keliru serta mampu bertumbuh meski menghadapi berbagai kesukaran. ${ }^{19}$

Berdasarkan hasil buah pikiran Randolph Crump Miller terdapat empat alasan pokok belajar sebagai identitas dan tugas gereja, yaitu: Pertama, kunci pemikir dan pekerja gereja di bidang pendidikan Kristen adalah teologi yang relevan. Teologi yang relevan yang dimaksudkan Miller adalah bahwa pemikir dan pekerja pendidikan Kristen terkait belajar sebagai identitas dan tugas gereja harus memahami hubunganhubungan yang erat: (a) antara teologi dan pengalaman pribadi. Pengalaman pribadi yang dimaksudkan adalah pengalaman ditebus oleh Allah dalam Yesus Kristus dan juga yang akan menebus orang lain. Pengalaman pribadi kita itu harus kita lihat dari prakarsa Allah masa kini dan juga warisan orang beriman masa lampau; (b) antara isi PAK dengan metodologi. Isi kurikulum harus bertumbuh lebih banyak melalui mutu hubungan kita ketimbang melalui gagasan agamawi. Metode-metode terbaik dan isi kurikulum dipakai sebagai sarana untuk mengantar para pelajar ke dalam hubungan yang benar dengan Allah; (c) antara kebenaran dan kehidupan. Pembangunan teori dan praktik PAK harus mendorong setiap orang Kristen yang datang untuk belajar megalami kebenaran Kristen sesuai dengan tahap perkembangannya. Untuk itu teologi harus melatar belakangi dan menjadi titik tolak untuk memahami kebenaran Kristen dalam mengungkap identitas dan tugas gereja sebagai pribadi pembelajar; Kedua, inti utama pendidikan agama Kristen dalam menemukan identitas dan tugas belajarnya haruslah dimulai dari pengenalan akan Allah dan untuk memuliakan Allah itu sendiri; Ketiga, rumah tangga Kristen merupakan lingkungan pertama bagi pelaksanaan pendidikan Kristen. Di sana anak belajar mempercayakan diri pada pemeliharaan orang lain dan bahwa orang lain dapat dipercayainya. Singkatnya, tiap-tiap anggota keluarga belajar pada mutu dan bahasa hubungan antara orang yang terlibat dalam lingkungan keluarga tersebut sebagai dasar segala pengalaman belajar agamawi; Keempat, secara praktis

${ }^{19}$ B. S. Sidjabat, Mengajar Secara Profesional: Mewujudkan Visi Guru Profesional (Bandung: Kalam Hidup, 2008). 
ada tiga pengajar utama, yakni lingkungan rumah tangga, jemaat dan korps guru.

Dalam hal ini Miller membedakan antara dua pengalaman, yakni belajar dan beriman. Keterampilan guru tidak dapat menghasilkan iman dalam diri seorang pelajar, melainkan Allah sendiri di dalam "kekayaan Kristus"; Kelima, berdasarkan bukunya yang berjudul, Biblical Theology and Christian Education, Miller merumuskan lima ruang lingkup kurikulum pembelajaran, yaitu: Penciptaan, Perjanjian, Penebus, Persekutuan dan Penggenapan, dan ditambah satu bagian lagi, yakni Penggenapan. ${ }^{20}$

Daniel Nuhamara melihat tugas utama dari pengajaran Kristen adalah mengomunikasikan iman Kristen yang harus dirumuskan dan dinyatakan secara teologis. Oleh sebab itu isi dari pengajaran Kristen mulai dari anak-anak sekolah minggu sampai dewasa harus sarat dengan muatan teologis. Selanjutnya landasan teologi dibawa ke dalam tiap-tiap isi pengajaran di jemaat sesuai dengan kekhasan tiap-tiap kelompok usia dari segi kebutuhan, minat, persoalan maupun tingkat pertumbuhannya. Untuk itu diperlukan model pengajaran kategorial seperti yang sudah ada sekarang ini: anak-anak, remaja, pemuda, orang dewasa, ibu-ibu, kaum wanita dan kelompok lanjut usia.21

D. Campbell Wycoff menegaskan bahwa Allah sendiri adalah guru di dalam pendidikan Kristen. Ini sesuai dengan rujukan Yesus kepada Roh Kudus sebagai seorang guru yang memandu para murid-Nya "ke dalam semua kebenaran" (Yoh. 14:26; 16:13). Dengan demikian di dalam pendidikan Kristen, Allah Tritunggal - Bapa, Anak, dan Roh Kudus adalah guru tertinggi. Namun pun demikian menurut Wycoff setiap anggota jemaat perlu dilibatkan di dalam pekerjaan dari pengajaran Kristen, untuk ia menjadi bagian dari suatu persekutuan yang terus menerus mengajar. ${ }^{22}$

C. L. J. Sherril berpendapat bahwa Allah adalah sebagai pengajar utama, karena Dialah yang memprakarsai hubungan dengan manusia. Pengajar kedua adalah jemaat sebagai koinonia, yang memainkan peranan yang begitu besar dalam pelayanan pendidikan agama Kristen. Dan pengajar yang ketiga adalah guru, yang wajib menyelenggarakan pengalaman belajar demi pelaksanaan komunitas yang paling mendalam. ${ }^{23}$ Dalam hal ini kedudukan pendeta menjadi sangat penting sebagai pusat kehidupan dan keaktifan pengajaran di jemaat. Oleh karena itu pendeta diharapkan menjadi seorang guru yang cakap dalam memajukan kerohanian anggota-

${ }^{20}$ Dalam karya Robert Boehlke yang berjudul Sejarah Perkembangan Pikiran dan Praktek Pendidikan Agama Kristen Jilid II, 694-695.

${ }^{21}$ Daniel Nuhamara, Pembimbing PAK (Bandung: Jurnal Infomedia, 2007), 74, 206.

${ }^{22}$ Colson dan Rigdon, Understanding Your Church's Curriculum, 21-22.

${ }^{23}$ Boehlke, Sejarah Perkembangan Pikiran dan Praktek Pendidikan Agama Kristen Jilid l, 725. 
anggota jemaatnya melalui pengajarannya. ${ }^{24}$ Misi pendeta adalah memedulikan: isi, orang-orang, dan konteks tentang pengajaran. Pengajarannya harus berdampak pada mental, afektif, dan pelajaran dimensi tingkah laku jemaat yang diajar. ${ }^{25}$

Berikut ini adalah empat poin penting yang harus dipahami dan dijadikan oleh gereja sebagi landasan bagi pemikiran dan pelaksanaan tugas pendidikan Kristen dalam membina dirinya sendiri dan warganya, terkait dengan identitas dan tugasnya dalam belajar.

\section{Sentralitas Alkitab dalam Penemuan Identitas dan Tugas untuk Belajar}

Meskipun gereja adalah tubuh Kristus, umat Allah, dan pesekutuan orang percaya, namun ia juga merupakan institusi (lembaga) yang membawa umat untuk bertumbuh dalam iman kepada Allah melalui Yesus Kristus, oleh firman-Nya. Gereja terpanggil untuk melaksanakan tugas belajar. Alkitab sendiri (2 Tim. 3:16) memberi penegasan bahwa ia adalah firman Allah yang sangat bermanfaat untuk: mengajar, menyatakan kesalahan, memperbaiki kelakukan. dan mendidik orang dalam kebenaran.

Alkitab mencatat penyataan diri dan kehendak Allah melalui kata (sabda), di mana ia memakai para nabi dan rasul sebagai penulis. Roh Allah sendiri membimbing para penulis dalam mengungkap kehendak Allah, sehingga mereka beserta tulisannya dibebaskan dari kekeliruan atau kepalsuan (2 Ptr. 1:20, 21). ${ }^{26}$ Alkitab sendiri memberi kesaksian bahwa firman Allah memiliki kuasa untuk mengubah kehidupan dari manusia yang membaca dan memahaminya. Mazmur 119, sangat terkenal berisi ungkapan yang dalam tentang kuasa pengajaran Allah. Misalnya dalam ayat 105 mengatakan: "Firman-Mu itu pelita bagi kakiku dan terang bagi jalanku". Yesus juga (Yoh. 8:31-32; 17:17) menegaskan bahwa firman Allah adalah kebenaran yang mampu membebaskan orang dari belenggu kepicikan (moral, etis, spritual). Begitu juga penulis kitab Ibrani menegaskan bahwa firman Tuhan itu bagaikan pedang bermata dua, sanggup menusuk amat dalam (Ibr. 4:12).

\footnotetext{
${ }^{24}$ Homringhausen dan Enklaar, Pendidikan Agama Kristen, 51-60.

${ }^{25}$ Pazmino, God Our Teacher, 129.
}

${ }^{26}$ Dalam bahasa Wayne Grudem, Sytematic Theology: An Introduction to Biblical Doctrine (Grand Rapid, Michigan: Zondervan, 1994, 78), karena Alkitab diilhamkan Allah maka ia memunyai sejumlah sifat, yakni: berotoritas (authority), mengandung kejelasan (clarity), mendorong kita untuk membaca dan mempelajarinya (necessity), serta sangat memadai (sufficient) untuk membantu kita mengerti kehendak Allah. Berdasarkan hasil pengalaman, saya sendiri berkeyakinan bahwa "kebodohan" dari ranah kognitif, afektif dan psikomotorik hanya dapat dientaskan dimulai dengan penundukan akal dan kehendak manusia pembelajar itu pada kepada Alkitab, firman Allah itu. 
Oleh sebab pemikiran yang telah dikemukakan di atas, sudah sepatutnya belajar dalam konteks pendidikan kristen bagi warga jemaat harus mengembangkan pelayanannya dengan melihat model-model pendidikan yang Allah kerjakan bagi dan melalui manusia. Penguasaan dalam artian intelektual (kognitif) bukanlah tujuan akhir pendidikan orang dewasa. Sebab penguasaan Kitab Suci bisa saja terjadi dalam hidup peserta didik tetapi tidak membuahkan kehidupan yang takut akan Allah. Hidup yang dikuasai atau didorong oleh kesucian dan kasih Allah tidak nyata. Tidak terlihat perubahan hidup dari segi moral, etis dan sosial. Jika belajar memakai bentuk persekutuan (fellowship), Alkitab haruslah menjadi sentral. Model persekutuan yang Allah kehendaki terjadi dalam hubungan sesama kita adalah berlandaskan kasih setia (bdg. 1 Kor. 13:47). Kepada jemaat di Kolose, rasul Paulus mendesak agar jika mereka bersekutu, berkumpul, mereka membicarakan firman Allah (Kol. 3:16). Jika belajar dengan pendekatan perkembangan iman, Alkitab perlu bersifat sentral. Alkitab sendiri menyatakan bahwa iman bertumbuh dari pendengaran terhadap firman Allah (Rm. 10:17).

Jika pembinaan orang dewasa berbicara sekitar masalah pembebasan hidup manusia dari keterbatasannya, Alkitab banyak berbicara mengenai perkara ini. Misalnya kasus pembebasan umat Israel dari Mesir, ini menjadi contoh penting bagaimana Allah bertindak sebagai pembebas dalam kehidupan manusia. Allah bertindak sebagai pembebas melalui kehidupan para hakim, nabi dan raja. Begitupun dalam kegiatan penafsiran realitas kehidupan dewasa ini untuk mengetahui maknanya, Alkitab tetap dapat memberi pengarahan. Sebab firman Allah sendiri mendesak kita berjaga-jaga serta membaca tanda-tanda zaman. Kita mesti pandai menguji segala perkara, agar mengerti yang berkenan pada Tuhan (bdg. 1 Tes. 5:19-21).

\section{Tugas Belajar dimulai dari Memahami Keutamaan Yesus Kristus}

Pengenalan mengenai siapa Tuhan Yesus Kristus sangat memengaruhi sikap hidup dan spiritualitas kita sendiri. Karena itu, kita harus senantiasa menyadari bahwa Yesus Kristus adalah pusat atau inti iman Kristen. Alkitab memberi pengajaran akan dua sisi kepribadian Yesus, yakni yang berdimensi ilahi dan yang manusiawi (Yoh. 1:1-18). Injil Yohanes menyatakan bahwa Yesus sajalah yang berkuasa memberikan hidup sejati hingga kekekalan (Yoh. 3:16, 10:10; 14:6). ${ }^{27}$

${ }^{27}$ Dalam bukunya J. I. Packer yang berjudul Knowing God: Tuntunan Praktis untuk Mengenal Allah (Yogyakarta: ANDI, 2008), 360, pada akhirnya memberikan empat kesimpulan tentang pentingnya belajar mengenal Allah dalam Kristus, pertama: dengan mengenal Allah, kita menemukan bahwa Allah yang ada "di sana" untuk kita kenal adalah Allah Alkitab...; kedua, pada saat kita melakukan pengenalan, kita belajar mengevaluasi ulang diri kita sebagai mahluk yang telah jatuh dalam dosa, tidak kuat, 
Teori belajar harus mengajarkan bahwa gambaran manusia ideal itu tak akan dapat kita temukan pada manusia itu sendiri. Kita hanya menemukan diri manusia yang datang dari atas, dari hadirat Allah sang pencipta alam semesta, yakni Yesus Kristus. Langkah awal untuk memperolehnya adalah memiliki relasi dinamis dengan Dia, menerima Dia ke dalam kehidupan, sebagai Tuhan dan juruselamat pribadi. Roh Allah yang Maha Kudus memeteraikan relasi itu. Selanjutnya kita harus bertumbuh ke dalam relasi yang lebih dalam lagi dengan Yesus Kristus, di dalam Roh dan kebenaran-Nya. Dengan perkataan lain, belajar tidak bebas dari pemberitaan Injil guna mendesak orang bertobat dan berpaling, serta percaya kepada Tuhan Yesus Kristus. Keutamaan Yesus juga harus mendorong si pembelajar untuk membimbing pelaku pendidikan (pendidik dan peserta didik) menjalani hidup berpusatkan Kristus.

Teori belajar dengan bentuk pembebasan dapat dilakukan dengan meneladani perbuatan Yesus Kristus, yang oleh Injil disebut juga sebagai pembebas (liberator) (bdg. Luk. 4:18-21). Yesus membebaskan manusia dari dosa, kuasa, kegelapan, kuasa iblis, kebodohan, penyakit serta kelemahan. Karenanya, program pembebasan dalam teori belajar dapat kita kembangkan dengan menyimak pengajaran dan perbuatan Yesus Kristus. Ada kegiatan pembebasan itu yang meski dilakukan dengan perjumpaan kuasa Allah menghadapi kuasa si jahat (power ministry). Ada pula dengan perbuatan diakonia dalam arti membantu mereka yang berkekurangan. Ada pula pembebasan dilakukan dengan kegiatan pendidikan dan pembelajaran.

\section{Identitas Manusia Pembelajar adalah Pembawa Imago Dei}

Di dalam Alkitab dapat kita temui pemahaman bahwa manusia adalah makhluk individu dan sosial (bdg. Kej. 1:26, 27). Sebagai individu, Allah menciptakan manusia memiliki dimensi fisik (jasmani), dan non fisik (roh, jiwa, hati, pikiran, kehendak). Adanya dimensi fisik (lahiriah) dan fisik (batiniah) dalam individu, harusnya membawa kita ke pemahaman akan realitas kebutuhan manusia yang serba dimensi. Kebutuhan fisik (jasmani) meliputi hal: sandang, pangan, kesehatan,

dan tidak mampu mencukupi diri sendiri seperti yang kita bayangkan sebelumnya. Kita menjadi lemah, bodoh, dan sesungguhnya buruk, dan tidak sedang menuju utopia, tetapi menuju neraka, kecuali kasih karunia Allah turut campur di dalamnya; ketiga, kita juga melihat bahwa mengenal Allah melibatkan hubungan pribadi di mana Anda menyerahkan diri kepada Allah berdasarkan janji-Nya untuk memberikan diri-Nya kepada Anda. Mengenal Allah berarti meminta kemurahan-Nya dan bersandar pada tindakan-Nya mengampuni orang-orang berdosa demi Yesus; keempat, mengenal Allah berarti menjadi murid Kristus, Juru Selamat hidup yang ada "di sana" hari ini, dan memanggil orang-orang yang membutuhkan kepada diri-Nya seperti yang Ia lakukan di Galilea pada saat Ia hidup di bumi. 
keindahan atau kebersihan. Kebutuhan intelektual, meliputi kemampuan berpikir secara tepat dan sehat, membuat perencanaan hidup, mengadakan pertimbangan dengan hikmat dan pengetahuan. Kebutuhan emosional, seperti: perasaan aman dan damai, sikap tenang dan menguasai diri, pengalaman-pengalaman yang berkaitan dengan jiwa dan hati. Kebutuhan kehendak (will), yang berani aktif dalam pengambilan keputusan dan motivasi. Kebutuhan rohani (spiritual), berkaitan dengan pembaharuan dan penyegarannya.

Sebagai makhluk sosial, manusia memiliki kebutuhan dan tanggungjawab. Kebutuhan berkarya atau bekerja - motivasi dan strategi pengembangan keterampilan; masalah profesionalisme; visi dan panggilan. Kebutuhan dalam kehidupan keluarga - relasi suami-istri; orang tua-anak; keluarga inti-keluarga batin (famili-famili). Kebutuhan dalam kehidupan ekonomi - menajemen keuangan. Kebutuhan dalam tanggungjawab politik - sebagai warga negara. Kebutuhan dalam sikap terhadap kebudayaan dan tradisi (adat). Kebutuhan dalam pola-pola komunikasi yang membangun.

Melihat keterangan di atas, teori belajar harus berupaya memperkaya peserta didik mengenal jati dirinya sebagai makhluk sosial, agar dengan demikian mereka dapat memainkan peran sebagai "garam dan terang dunia". Sebab dalam Injil kita temukan bahwa transformasi yang dikerjakan oleh Yesus tidak saja menyangkut soal kehidupan pribadi, tetapi juga menembusi kehidupan sosio-kultural. Karena itu bidang-bidang kajian yang dapat dikembangkan oleh si pembelajar begitu luas. Artinya si pembelajar memiliki kesempatan yang baik bagi pengembangan kualitas hidup individu maupun kelompok.

\section{Peran Pribadi dan Karya Roh Kudus dalam Penemuan Identitas dan Tugas Belajar}

Roh Kudus hadir untuk memberikan berbagai macam karunia, sesuai dengan kehendak-Nya sendiri (bdg. 1 Kor. 12:1-11; Ef. 4:11-13; Rm. 12:6-8). Oleh sebab itu, pengajaran Roh Kudus bagi gereja yang bersedia belajar amat penting kita sajikan kepada warga jemaat, supaya mereka lebih mengerti arti kehidupan kristiani secara dinamis. Ketika orang membuka dirinya kepada kehadiran dan pekerjaan Roh Kudus, maka hidup dan karyanya menjadi sangat efektif dan kreatif. Sebab Roh itu sendiri yang menyatakan kehadiran, hikmat, kuasa dan kasih daripada Yesus Kristus. Roh Kudus pula yang membawa orang percaya yang sedang belajar itu memahami salib Yesus beserta maknanya yang luar biasa. Hidup bersama dan berjalan dengan Roh Kudus ialah hidup yang membawa kita berpusatkan salib Yesus Kristus (bdg. Gal. 5:16-25; 6:14). Roh yang sama membawa kita kepada pengenalan dan pemahaman yang lebih dinamis lagi mengenai siapa Allah Bapa Yang Maha Agung. 
Apa keterangan Alkitab mengenai pribadi dan karya Roh Kudus harus dijelaskan. Harus disadari bahwa dalam membaca dan memahami ajaran Alkitab, pengalaman hidup, tradisi dan kebiasaan gereja (denominasi), pola pikir, juga temperamen, ikut memengaruhi. Jika tidak hati-hati, warga jemaat dapat memahami peran Roh Kudus dalam kehidupan secara tidak proporsional. Roh Kudus hadir dan berkarya memberkati peserta didik melalui pribadi dan kehidupan pendidik. Selain itu Roh Kudus juga bekerja dalam diri si pembelajar (pendidik dan peserta didik) menumbuhkan pengertian mereka serta memberikan motivasi sehingga bersukacita mengikuti kegiatan belajar. Roh Kudus juga berkarya melalui firman Tuhan yang diteliti, dipelajari dan diperbincangkan. Roh Kudus juga menginspirasikan Firman, juga menyingkapkan rahasia Firman itu. Dalam melalui interaksi pendidik dan peserta didik serta sesama peserta didik, Roh Kudus berkarya sehingga komunikasi dan relasi menjadi akrab dan saling melengkapi. Yang tidak kalah penting, Roh itu menghadirkan hikmat dan berkat-Nya melalui lingkungan fisik, sosial, sarana dan prasarana yang dipergunakan. Kalau kehadiran Roh Kudus diakui dan diandalkan, maka proses belajar akan sangat berkualitas. ${ }^{28}$

\section{Kesimpulan}

Pandangan teologis kita mengenai gereja (ekklesiologi) turut memengaruhi pemikiran tentang strategi pengelolaan pelayanan kita sendiri. Jika kita memandang gereja sebagai institusi organisasi belaka, maka segala bentuk pelayanan di dalam gereja itu akan kaku karena dikontrol ketat oleh berbagai peraturan (birokrasi). Gereja dikelola hanya kaum "klerus" (seperti gembala sidang, majelis, guru jemaat dan guruguru sekolah minggu) yang ditetapkan oleh gereja sesuai peraturan yang berlaku. Warga gereja harus mengikuti pertimbangan kaum "klerus" di dalam kehidupan berjemaat. Sistem demikian umumnya jemaat memilih penonton (pasif).

Hendrik Kraemer mengemukakan bahwa apabila gereja menganggap kaum "klerus" saja yang "berhak" melayani, maka kehidupan gereja kurang berkembang. Karena itu dia mengusulkan, pembaruan

${ }^{28}$ Gary Newton, "The Holy Spirit in the Educational Process," dalam Introducing Christian Education: Foundation for the Twenty-first Century, ed. Micharl J. Anthony (Grand Rapids, Mich.: Baker Academic, 2001), 125-129. Secara lebih lengkap bahasan tentang keterlibatan Roh Kudus dalam pembelajaran dibicarakan oleh Roy B. Zuck, dalam Spiritual Power in Your Teaching (Chicago: Moody Press, 1963), 223. Juga dalam karya Robert W. Pazmino dengan topik "God in Us: The Holy Spirit in Teaching” dalam God Our Teacher: Theological Basis in Christian Education (Michigan: Baker Akademic, 2001), 87112. 
pemikiran dimulai dari pemahaman teologis. Maksudnya, semua warga gereja perlu mendapat pemahaman bahwa setiap orang percaya memiliki "akses" atau kesempatan yang sama melayani Tuhan. Kraemer: kaum "awam" dan kaum "klerus" semuanya sederajat di hadapan Allah, samasama umat tebusan darah Yesus Kristus, dasar dan kepala gereja itu sendiri. ${ }^{29}$

Berkaitan dengan teori belajar, tugas kita sangat mendesak, yakni bagaimana membimbing warga gereja memiliki pemahaman yang benar mengenai kedudukan dan peran gereja. Artinya, isu-isu kegerejaan tidak boleh hanya menjadi "urusan" para pekerja gereja, tetapi juga menjadi buah pemikiran warga jemaat. Hal demikian akan menumbuhkan rasa kecintaan (sense of belonging) dalam diri mereka terhadap gereja. Rasa cinta akan melahirkan keinginan untuk berkarya dan berkorban bagi pengembangan gereja Tuhan di bumi ini.

Gereja mengalami hidup yang dinamis, sebagaimana diungkapkan oleh Richard Lovelace ${ }^{30}$ diperlukan tiga pra-kondisi dalam belajar, pertama, orang harus memiliki kesadaran yang dalam akan kekudusan Allah, menyangkut kasih dan keadilan. Juga diperlukan kesadaran akan betapa dalamnya dosa yang ada dalam dirinya sendiri di tengah-tengah masyarakat atau dunia. Kesadaran ini dapat terjadi lewat pemberitaan Injil yang jelas dan tegas. Karena itu, berita dan pemberitaan Injil menjadi sangat penting bagi semua orang.; kedua, pemahaman akan dalamnya rahmat Allah yang kita peroleh di dalam dan melalui Tuhan Yesus Kristus. Di dalam Yesus Kristus kita yang percaya memperoleh banyak hal dari Allah, yakni "segala berkat rohani dalam sorga" (Ef. 1:3); ketiga, pemahaman akan kedudukan dan tugas gereja menurut kehendak Allah. Gereja adalah agen kerajaan Allah di bumi ini, yang tidak akan dikalahkan oleh alam maut sekalipun (Mat. 16:18). Karena itu setiap orang percaya perlu memiliki pengertian yang jelas dan benar mengenai tugas gereja, yakni: (a) mengemban misi, proklamasi Injil dan keterlibatan sosial; (b) mengaktifkan kehidupan doa, sebagai gaya hidup ketergantungan kepada Allah; (c) memahami identitas umat, memelihara persatuan dan persatuan; (d) bersikap kristis terhadap nilai-nilai budaya, secara konstruktif dan realistis; (e) pembentukan pemikiran Kristen yang secara integratif menyatakan kebenaran dan kritik terhadap budaya.

Guna membimbing gereja berkembang dalam kehidupan yang dinamis secara spritual, tentulah kehadiran gereja yang bersedia belajar sangat diperlukan. Melalui kegiatan belajar gereja dapat membina individu dan kelompok agar memahami dinamika pembentukan

${ }^{29}$ Hendrik Kraemer, Teologi Kaum Awam (Jakarta: BPK Gunung Mulia, 1981), 32.

${ }^{30}$ Richard F. Lovelace, Dynamics of Spiritual Life: An Evangelical Theology of Renewal (Grand Rapids, Michigan: InterVarsity, 1970), 223. 
spritualitas. Warga jemaat perlu kita sadarkan bahwa untuk memelihara kadar spiritualitas yang tetap segar, orang percaya senantiasa memerlukan "suntikan-suntikan" berupa pembelajaran yang jujur, sehat dan benar. Tidak cukup belajar hanya melalui KKR (kegiatan kebangunan rohani). Pembinaan dalam rangka membelajarkan jemaat dapat lebih praktis mengelola program-program berupa retret, di mana dalam kelompok yang lebih kecil, orang dapat belajar dan memberi pengalaman hidup bagi sesamanya (baik dari kegagalannya maupun dari kesuksesannya). Program pembinaan jemaat juga dapat menciptakan program-program seminar, diskusi, lokakarya, dan sejenisnya, dalam rangka meningkatkan kualitas spiritualitas jemaat.

\section{Kepustakaan}

Anthony, Micharl J. (ed.). Introducing Christian Education: Foundation for the Twenty-first Century. Grand Rapids, Mich.: Baker Academic, 2001.

Beechick, Ruth. Biblical Psychology of Learning. Acćent Books, 1982.

Boehlke, Robert. Sejarah Perkembangan Pikiran dan Praktek Pendidikan Agama Kristen Jilid II. Jakarata, BPK Gunung Mulia, 2010.

Budi Ningsih, Asri C. Belajar dan Pembelajaran. Yogyakarta: Rineka Cipta, 2005.

Colson, Howard P., Raymon M. Rigdon, Understanding Your Church's Curriculum. Nasville, Tennessee: Broadman Press, 1981.

Cruickshank, W. M. Psychology of Exceptional Children and Youth. New York: Prentice Hall Inc, 1980.

Delnay, Robert G. Teach as He Taugh. Chicago: Moody Press, 1987.

Francis A. Schaeffer, dalam The God Who Is There (InterVarsity Press, 1998.

Gladwell, Malcolm. The Tipping Point: How Little Things Can Make a Big Difference. Boston: Little, Brown, 2000.

Hadiwijono, H. Iman Kristen. Jakarta: BPK Gunung Mulia, 1979.

Harris, M. Fashion Me a People:Curriculum in the Church. Louisville, KY Westminster John Knox Press, 1989.

Harris, Maria. Fashion Me a People:Curriculum in the Church. Louisville, KY: Westminster John Knox Press, 1989.

Hendrick, Howard G. Teaching to Change Live. Portland: Multnomah, 1978. Hendrik Kraemer, Teologi Kaum Awam.Jakarta: BPK Gunung Mulia, 1981. Homringhausen, E. G. dan Enklaar, I. H. Pendidikan Agama Kristen. Jakarta: BPK Gunung Mulia, 1999.

Howard P. Colson dan Raymond M. Rigdon, Understanding Your Church's Curriculum. Nashville, Tennessee: Broadman Press, 1981. 
Howard P. Colson dan Raymond M. Rigdon. Understanding Your Church's Curriculum. Nashville, Tennessee: Broadman Press, 1981.

Ken Sidney, The Blackboard Fumbleed (Victor Books, 1989), 95-97.

McKenzie, L. The Religion Education of Adults. Birmingham, Ala: Religious Education Press, 1982.

Moleong, Lexy J. Metodologi Penelitian Kualitatif. Bandung: Remaja Rosdakarya, 2006.

Nuhamara, D. Pembimbing PAK. Bandung: Jurnal Infomedia, 2007.

Packer, J. I. Knowing God: Tuntunan Praktis untuk Mengenal Allah. Yogyakarta: Penerbit ANDI, 2008.

Pazmino, Robert W. God Our Teacher: Theological Basis in Christian Education Grand Rapids, Michigan: Baker Academic, 1992.

Pazmino, Robert W. Principles and Practices of Christian Education. Grand Rapids, Michigan: Baker Book House, 1992.

Richard F. Lovelace, Dynamics of Spiritual Life: An Evangelical Theology of Renewal. Michigan: InterVarsity, 1979.

Robert R. Boehlke. Sejarah Perkembangan Pikiran dan Praktik Pendidikan Agama Kristen Jilid II. Jakarta: BPK Gunung Mulia, 2005.

Sidjabat, B. S. Mengajar Secara Profesional: Mewujudkan Visi Guru Profesional Bandung: Kalam Hidup, 2008.

Sidjabat, B. Samuel. Strategi Pendidikan Kristen. Yogyakarta: ANDI, 1996.

Stubblefield, Jerry M. (ed.). A Church Ministering To Adults (Nasville, Tennessee: Broadman Press, 1986.

Sukardi, Metodologi Penelitian Pendidikan: Kompetensi dan Praktiknya. Jakarta: Bumi Aksara, 2005.

Sukmadinata, Nana Syaodih. Landasan Psikologi Proses Pendidikan. Bandung: Rosadakarya, 2007. 